\title{
FISCAL POLICY DISCLOSURE IN INDONESIAN LOCAL GOVERNMENTS
}

\author{
Johan Arifin, \\ Universitas Islam Indonesia, Curtin University Perth Australia \\ e-mail: johan.smile@yahoo.com \\ Greg Tower \\ Curtin University, Perth Australia \\ e-mail: G.Tower@curtin.edu.au \\ Stacey Porter \\ Curtin University, Perth Australia \\ e-mail: Stacey.Porter@cbs.curtin.edu.au
}

\begin{abstract}
This study investigates the level of fiscal policy disclosure within financial statements of Indonesian local governments. Indonesia is a developing country that has recently undergone major state financial reform. Isomorphic institutional theory is adopted as the underlying theoretical framework. There is a high level of communication as measured by the Fiscal Policy Compliance Index $(81.2 \%)$. Regression analysis shows that the coercive isomorphism variable, measured by number of parliamentarians, is positive and statistically significant predictor of the extent of fiscal policy disclosure. Local governments that have more parliamentarians in their jurisdiction communicate more extensively. In addition, the age of local governments and financial independence variables affect the extent of fiscal policy disclosure in Indonesian local governments.
\end{abstract}

Keywords: financial statement, fiscal policy disclosure, developing countries.

\begin{abstract}
Abstrak
Studi ini meneliti tingkat pengungkapan informasi kebijakan fiskal dalam laporan keuangan pemerintah daerah Indonesia. Indonesia adalah sebuah negara berkembang yang baru saja melalukan reformasi keuangan negara secara komprehensif. Teori institusional isomorphic diadopsi sebagai teori yang mendasari studi ini. Hasil studi ini menyatakan bahwa terdapat tingkat pengungkapan informasi kebijakan fiskal yang tinggi dalam laporan keuangan pemerintah daerah yang diukur dengan index ketaatan kebijakan fiskal yaitu 81,2\%. Analisis regresi menunjukkan bahwa variabel 'coercive' yang diukur dengan jumlah anggota dewan merupakan prediktor terhadap tingkat pengungkapan informasi kebijakan fiskal. Pemerintah daerah yang mempunyai lebih banyak jumlah anggota dewan lebih intensif mengkomunikasikan informasi kebijakan fiskalnya. Selain itu, umur pemerintah daerah dan ketergantungan keuangan juga mempengaruhi tingkat pengungkapan informasi kebijakan fiskal pada pemerintah daerah Indonesia.
\end{abstract}

Kata kunci: Laporan keuangan, pengungkapan informasi kebijakan fiskal, negara berkembang.

\section{INTRODUCTION}

Indonesia is a developing country in Asia that has recently undergone comprehensive reform to improve economic conditions. Indonesia's economy can be measured by using several indicators such as national income and Gross
Domestic Product (GDP) (Suliswanto and Kaluge 2010). The government of Indonesia has a range of policies to maintain or improve the quality of Indonesia's economy. One key element is fiscal policy. According to Talvi and Vegh (2005) fiscal policy is made by the 
government to direct a country's economy through government spending and revenues via their budget. The budget consists of tax revenue, government spending, and government transfers. Taylor (2000) states that fiscal policy has two main instruments, namely tax policy and expenditure policy to influence of state revenues and expenditures on the state economy, unemployment, and inflation.

Government has a power to collect public revenue and shall use it to finance the activities to provide services to the public. The government should be accountable for such activities transparently. In order to establish accountability and transparency, Indonesia has issued Government Regulation No.24 of 2005 regarding the Governmental Accounting Standards, and No.8 of 2006 on the Financial Reporting and Performance of Government Agencies. These apply to the central government and local government. As required by the Indonesia government accounting standard, information on fiscal policy is a part that must be disclosed in financial statements across all government agencies, in other words information of fiscal policy is a mandatory disclosure.

In UU No.22 of 1999 local governments were given authority to set their own appropriate regulations. This condition causes a high accountability for every local government in Indonesia. In connection with the implementation of government regulations (PP) No.24 of 2005 about the governmental accounting standard, it is important to study the extent of local government communication. How do they implement the fiscal policy disclosure requirements in their financial statement? UU No. 17 of 2003 requires for any local governments in Indonesia to make an an- nual financial report in accordance with applicable governmental accounting standards.

There is a clear need to research local government compliance. For example, in 2009 the Supreme Audit Board of the Republic of Indonesia that is also known as Badan Pemeriksa Keuangan (BPK) claims that the financial statements of local governments in Indonesia have not met expected targets. The Board which is the highest (supreme) audit institution in the land is responsible for the auditing of the state finance sector, i.e. the budget implementations of the central government and local government, the state-owned enterprises, and those enterprises owned by the local governments in short, the entire wealth of the government. They state many Indonesian local governments have not fully prepared financial statement in accordance with standards and regulations. Herawaty and Susanto (2008) argue that to obtain an unqualified opinion for Indonesian local government entities, there are four criteria that need to be considered including: compliance with accounting standards, the effectiveness of internal control, compliance with laws and regulations and the adequacy of disclosure (full disclosure). Table 1 highlights problems with compliance in Indonesian local governments.

Several studies of mandatory disclosure have been made by previous researchers such as Martani and Lestiani (2010) which states that the audit findings of local government influence governmental organizations in conducting their mandatory disclosure in their financial statements. Moreover, they state that the number and the value of audit findings affect the level of disclosure in the financial statements of organizations. They posit the higher the number of audit findings, the lower the level of disclosure in the financial statements.

Table 1: Financial Statement Audit Opinion: Indonesian local government 2007-2009

\begin{tabular}{cccccccccc}
\hline & \multicolumn{2}{c}{$\begin{array}{c}\text { Unqualified } \\
\text { Opinions }\end{array}$} & \multicolumn{2}{c}{ Qualified Opinions } & \multicolumn{2}{c}{$\begin{array}{c}\text { Disclaimer } \\
\text { Opinions }\end{array}$} & \multicolumn{3}{c}{ Adverse Opinions } \\
\hline Year & $\begin{array}{c}\text { Number } \\
\text { of entities }\end{array}$ & $\%$ & $\begin{array}{c}\text { Number of } \\
\text { entities }\end{array}$ & $\%$ & $\begin{array}{c}\text { Number of } \\
\text { entities }\end{array}$ & $\%$ & $\begin{array}{c}\text { Number } \\
\text { of entities }\end{array}$ & $\%$ & Total \\
\hline 2007 & $\mathbf{4}$ & $\mathbf{1 \%}$ & 283 & $61 \%$ & 121 & $26 \%$ & 59 & $13 \%$ & 467 \\
2008 & $\mathbf{1 3}$ & $\mathbf{3 \%}$ & 322 & $67 \%$ & 115 & $24 \%$ & 32 & $6 \%$ & 482 \\
2009 & $\mathbf{1 5}$ & $\mathbf{4 \%}$ & 315 & $72 \%$ & 70 & $16 \%$ & 35 & $8 \%$ & 435 \\
\hline Source: Supreme Audit Board of Indonesia
\end{tabular}


Copley (1991) investigates the influence of audit quality on the financial disclosure of local governments. The result provides evidence that there is positive relationship between audit quality and disclosure. Research in the private sector has found similar results where audit quality can induce the financial statement quality by improving the disclosure to reduce asymmetry information. Ingram (1984) concludes that the coalition of voters, administrative powers, and management incentives significantly helps explain variations in the disclosure level on governmental financial statements. Robbins and Austin (1986) also note that administrative power and management incentives are associated with the disclosure quality. Cheng (1992) develops a political economic model based on the theoretical and empirical work in public choice and political science to help explain state government accounting disclosure choice. The model posits that state government accounting disclosure choice is influenced by its political environment and institutional forces.

This study examines key variables that are expected to influence the level fiscal policy disclosure of financial statements in local governments in Indonesia. There are two important aspects to this study. First, this research uses institutional theory approach to examine the level of fiscal policy disclosure of financial statements of local governments in Indonesia. Second, the research is conducted in Indonesia, a developing country that has recently undergone major state financial reform and has a unique governmental structure $^{1}$.

\footnotetext{
${ }^{1}$ The territory of Indonesia is divided into autonomous provinces, districts (kabupaten) and municipalities (kota). Districts and municipalities are technically the same level of government. This distinction is based on whether the government administration is located in a rural area (district) or an urban area (municipality). Within districts and municipalities there are sub-districts (kecamatan) which are smaller administrative government units. Each sub-district is further divided into villages. Villages in rural areas are called desa, while in an urban areas there are referred to as kelurahan (Usman, 2001). This study focuses on the district and municipality levels. These are collectively referred to in this study as 'local government'.
}

\section{LITERATURE REVIEW AND HYPOTHESES DEVELOPMENT}

Studies on mandatory disclosure, including those examining disclosures of fiscal policy have adopted a variety of theories such as agency theory (Mahoney 2005), legitimacy theory (Mobus 2005), capital market theory (Schon 2006), and institutional theory (Yoshikawa, Tsui and McGuire 2007). Among these theories, agency theory and institutional theory are the most widely used by mandatory disclosure researchers (Mucciarone 2008). Recently, some researchers have employed institutional theory in the public sector area specifically on mandatory disclosure (e.g. Buhr and Freedman 2001). Sejjaaka (2004) posits that this theory potentially provides greater insights of mandatory disclosure practices. Accordingly, this study adopts institutional theory as the underlying theoretical framework explaining fiscal policy disclosure practices in Indonesia.

The local government is one type of public sector organization whose primary purpose is to provide public services. Mardiasmo (2002) argue that because it involves the use of public money then the government will get pressure from various parties (stakeholders) relating to the need for public accountability. The government stakeholders will continue to pressure local governments on the quality of public services and public accountability.

Institutional theory explains that organizations are faced with institutional pressures and due to these pressures those organizations tend to become very similar in their form and practices (Perera 2007; Deegan 2006). Institutional theory is concerned with how organizations structure themselves to gain acceptance and legitimacy which may be at the expense of efficiency. Legitimacy is the acceptance of an organization by certain social actors in society as not all parties have the standing to confer legitimacy. Pressures to conform arise from a variety of factors including uncertainty and task requirements, professional norms and standards, and a broader normative environment (Dacin 1977). 
Institutional theory has two main dimensions: isomorphism and decoupling (Deegan 2006). Isomorphism, as used in this study, refers to particular practices by an organization because of institutional pressures (DiMaggio and Powell 1983) while decoupling refers to a situation in which the apparent practice of an organization is different from the actual practice (Meyer and Rowan 1977). In the context of this study, it can be said that isomorphism is the process by which fiscal policy disclosure practice in a local government is influenced by institutional pressures. Whereas decoupling is a situation in which fiscal policy disclosure practice is used by an organization to create an image which is different from that organization's circumstances or activities. In accordance with the purpose of this research which relates to the factors that influence the level of mandatory disclosure (fiscal policy) in local governments, this study solely utilises the isomorphic institutional dimension as the underlying theoretical framework.

DiMaggio and Powell (1983, p.149) label the process by which organizations tend to adopt the same structures and practices as 'isomorphism', which they describe as a homogenization of organizations. Tolbert and Zucker (1983, p.17) state when describing municipality reform "...the rapid institutionalization of the reform rested on the assumed isomorphism between it and the ideal rational bureaucratic form". Several studies such as (Zucker 1987; Covaleski and Dirsmith 1988; and Tagesson and Falkman 2008) are based on institutional isomorphism in accordance with the concepts put forward by DiMaggio and Powel (1983).

As proposed by institutional theorists, by becoming 'isomorphic', organizations may achieve legitimacy (DiMaggio and Powell 1983). Kostova and Zaheer (1999) note that institutional theory supporters such as Powell and DiMaggio (1983) and Meyer and Rowan (1977) have identified some of the determinants of organizational legitimacy and the characteristics of the legitimating process. They cite three sets of factors that shape or- ganizational legitimacy: (1) the environment's institutional characteristics, (2) the organization's characteristics, and (3) the legitimating process by which the environment builds its perception of organizations. Furthermore, Kostova and Zaheer (1999, p.77) in their study on multinational enterprises, claim "given the multiplicity and variety of institutional environments and the cross country differences between these environments, achieving isomorphism becomes difficult". Carpenter (2001) and Ashworth, Boyne and Delbridge (2007) suggest that isomorphic pressures differ based on organizational characteristics. In a consistent theme, this study examines isomorphic variables such as size of local government, jurisdiction, and political influence, and their potential relationship with the level of fiscal policy disclosure.

Scott (1987) reviews four sociological formulations all claiming an institutional focus due to variations in definition on the concepts of institution and institutionalization. Scott (1987, p.499) describes institutionalization conceptions as "a process of instilling value; a process of creating reality; institutional systems as a class of elements and institutions as distinct societal spheres". This study considers several areas within institutional theory, including that describing institutional systems as a class of elements. According to Scott (1987, p.497), "institutionalized belief systems constitute a distinctive class of elements that can account for the existence and/or elaboration of organizational structure". Furthermore, he states that:

Since the concept of institutionalization is not definitionally linked to a distinctive process that might cause an organization to change its structure in ways that make it conform to-become isomorphic with-an institutional pattern. The best known-classification is of this type is developed by DiMaggio and Powell (1983) who distinguished among coercive, mimetic and normative processes leading to conformity. 
This study examines these three types of isomorphic pressures. Joseph (2010) reveals that the most noticeable type of institutional force is coercive isomorphism. According to DiMaggio and Powell (1983, p.149), "coercive isomorphism results from both formal and informal pressures exerted by other organizations on which an organization may be dependent, as well as cultural expectation in which the organizations operate". The formal pressure they refer to is a regulative process where regulators have the capacity to set up rules and procedures, monitor compliance and, when necessary, apply sanctions.

DiMaggio and Powell (1983, p.150) then explain "mimetic isomorphism is where organizations tend to model themselves and imitate the practices and policies of those organizations perceived to be legitimate and successful". Mimetic isomorphism is often referred to as a response to uncertainty. Furthermore, Baker and Rennie (2006, p.88) states that "while these organizations may not be certain about what they should do when facing challenges by adopting structures and processes used by similar organizations, they are, at the very least being seen to be doing something".

Ryan and Purcell (2004, p.10) state that "normative influences refer to shared norms of organizational members, that is, those values that may be unspoken, or expectations that have gained acceptance within organizations". The element of pressure is normally developed by professional and occupational groups (Rahaman et al. 2004). DiMaggio and Powell (1983) argue that the more highly professionalized a workforce becomes in terms of academic qualifications and participation in professional and trade associations, the greater the extent to which the organization becomes similar to other organizations in the fields. In addition, Baker and Rennie (2006, p.87) also cite another source of normative isomorphism, expertise, as a possible important resource in "the implementation of reform and help in identifying shortcomings in a practice".

\section{Coercive Isomorphism Related Hypothesis}

This study examines the independent variable size of local government within the framework of coercive isomorphism. Size of government organization has been examined previously in public sector accounting research as one of the stronger determinants of for example, choice of accounting standard or internet financial reporting. With regard to public sector accounting research, size of an organization has been found to have a positive relationship with the extent of disclosure in annual reports of state government (Taylor and Rosair 2000).

Several studies use size of local parliament ${ }^{2}$ as a measurement of local government size (see Hix 2004). In line with coercive isomorphism aspect of institutional theory, the local parliamentarians are thought to have the power to pressure local government executive to align with the society's aspirations. Accordingly this study uses the number of local representatives in parliament to measure size as a predictor of the level of fiscal policy disclosure in financial statements.

Local Parliament has a varying number of parliament members, depending on the size and influence of the local government. As stated in Indonesian Act No. 10 of 2008, a member of local parliament is a political mediator of the people within a local government. The greater number of local parliament members, means the greater local community representatives who will hold a legislative function to influence local government executives in performing their duties (Sotiropoulos 2008). Therefore, there is potential pressure from those local members representing local community as a coercive influence of local government executives to make more extensive disclosures on their operational activities. To capture this potential coercive pressure the following hypothesis is proposed:

H1: There is a positive association between size of local parliament and the extent of

\footnotetext{
${ }^{2}$ Under Act No. 27 of 2009, In Indonesia, there are three levels of parliament; those are state parliament, provincial parliament, and local parliament. This study focuses on the local parliament level consisting of districts and municipalities members.
} 
fiscal policy disclosure in the local government financial statements.

\section{Mimetic Isomorphism Related Hypothesis}

Within the framework of mimetic isomorphism, a hypothesis is developed to test the impact of jurisdiction. State or local government's jurisdiction is arguably a mimetic pressure in relation to institutional theory. DiMaggio and Powel (1983) suggest that mimetic behavior occurs as a reaction to uncertainty. When organizations face situations where there is no clear cut course of action, they may limit the selection of structures or practices to those that are being used by other organizations that are viewed as being successful in the institutional environment. Furthermore, Palmer (1993) states that organizations tend to model themselves after similar organizations in their field that are perceived to be more legitimate or successful. Thus, mimetic isomorphism is a response to organizational uncertainty in identifying the best course of action.

The capital city of Indonesia is located on the island of Java. The capital's Java location influences the surrounding area to get better facilities. Potentially the amenities in every local government located in Java may be better than non-Java. For instance, the government of Indonesia through the Ministry of Communications and Information (Kemkominfo) admit to having a clear gap in terms of construction and development of telecommunications facilities on the islands between Java and non-Java (Republika 2011). Ball (2001) and Olajumuke (2010) feel that the quality of telecommunication infrastructure will affect the quality of an entity's financial reporting. With a better communication system, an organization can more easily monitor its development, all matters relating to the operations can be shared to all stakeholders more quickly to support the advancement of the organization. In addition, Java has better educational facilities than non-Java with most of the leading universities being located in Java. It is therefore suggested that non Java local governments will potentially mimic administrative prac- tices of Java local governments, including the fiscal policy disclosure practices in the financial statements. The following hypothesis of mimetic behavior is proposed:

H2: There is a positive association between local governments that are located on the island of Java and the extent of fiscal policy disclosure in the local government financial statements as compared to nonJava entity.

\section{Normative Isomorphism Related Hypothesis}

Under normative isomorphism, a hypothesis is developed to test the impact of a possibly explanatory variable namely political influence. In the governance structure for public sector, local parliament is an institution that has an important check and balance function to ensure that the local government executives execute their job well in the interests of all stakeholders (Lyngstad 2010). Grigorescu (2008) interprets this function as horizontal accountability. This function can be used as an argument to support normative isomorphism pressure on local government executives to run the "professional activities" to meet the public interest. Moreover, Gaffikin and Lindawati (2012) define a professional activity as "an activity that has a strong motivation, sufficient knowledge, service oriented, and priority to public interest". A leader of local government should be professional in doing the work and must be independent of the political parties which have supported him/her in the election.

Meanwhile, Sopanah (2005) and Ying and Zhengfei (2006) state that a decline in the quality of supervision of the executive would result in decreased quality of disclosure on the executive accountability report, including disclosures on its financial statements.

Moreover, Silva (2009) argues that the composition of members of local parliament could be used as benchmarks to see the power of pressure exerted by the local parliament to the executive government. If the proportion of local parliament member is dominated by the majority party, and the chairman of local government is from the same party or a coalition, 
then the quality of supervision conducted on the performance of the executive may decline. Based on these ideas, the following hypothesis is proposed:

H3: There is a positive association between the proportion of local parliament members who are independent of the executive (chairman of the local government) and the extent of fiscal policy disclosure in the local government financial statements.

\section{RESEARCH METHODOLOGY}

From a total population of 496 local governments in Indonesia, a stratified random sam$\mathrm{ple}^{\mathbf{3}}$ of 80 financial statements is collected from the Badan Pemeriksa Keuangan (Supreme Audit Institution) database for the period ending December 31, 2009. The sample consists of 40 local governments in Java and 40 local governments outside Java. Both local governments' types are further divided into district and municipality groupings.

\section{Measurement Techniques Dependent Variable}

Informativeness of financial statements can be seen from the extent to which an entity provides an explanation (disclosure) on financial its financial statements (Ingram and DeJong 1987). In Indonesia, fiscal policy disclosure of local government statement is mandatory in accordance with the government regulation No. 24 of 2005 regarding Indonesian Government Accounting Standards. To examine the extent of fiscal policy disclosure in financial statements of Indonesian local governments, a Fiscal Policy Compliance Index (FPCI) is created.

Cook (1990) states that a disclosure index can be classified into weighted or un-

\footnotetext{
${ }^{3}$ A method of sampling that involves the division of a population into smaller groups known as strata. In stratified random sampling, the strata are formed based on members' shared attributes or characteristics. A random sample from each stratum is taken in a number proportional to the stratum's size when compared to the population. These subsets of the strata are then pooled to form a type of random sample (Reynolds, Simintiras \& Diamantopoulos, 2003). In this study, the division of strata includes district-municipality, old-new of local government, surplus-loss of local government, Java and non-Java.
}

weighted index. In a weighted disclosure index, particular disclosure items are given a higher score than the other disclosure items based on the perceived importance of those particular items. Whereas, in an unweighted index, each disclosure item is deemed equally important and therefore each item is awarded the same score when it is disclosed (Meek, Roberts and Gray 1995). Most prior studies use an unweighted disclosure index to measure the level of disclosure as this technique is considered far less subjective than a weighted index and is more relevant to all entities (Craig and Diga 1998). Accordingly, this study adopts an unweighted technique for scoring each fiscal policy disclosure item.

In the disclosure index (FPCI), the contents of each annual report are compared to the items listed on a checklist and coded as 1 or 0 , depending upon whether or not the content conforms to the items listed on the checklist (Coy, Tower and Dixon 1993). A fiscal policy disclosure index (FPCI) for every local government is then calculated as the ratio of total score awarded to the local government divided by the maximum number of items that are applicable for the entity. Such a measurement approach is suitable for measuring the level of disclosure in developing nations whose set of economic, politic and social conditions differ from those of developed nations (see Nurhayati, Brown and Tower 2006).

FPCI consists of six items of information relating to local governments fiscal policies. The items are adopted from the Indonesian government accounting standards (PP No.24 of 2005) that seek to communicate fiscal policy information in every local government. These items include information on revenue policy, expenditure policy, resource costs and usage, and comparison with previous periods of financial circumstances. The items can be used as an important benchmark to analyze how far local governments comm nicate their fiscal condition. Therefore, this study uses those six items of fiscal policy to assess the extent to which local governments provide an explanation of fiscal information in its financial statements. The initial analyses of 
the 80 Indonesia's local government financial reports are reported in figure 1.

Figure 1: Fiscal Policy Compliance Index (FPCI) in 2009 (by items)

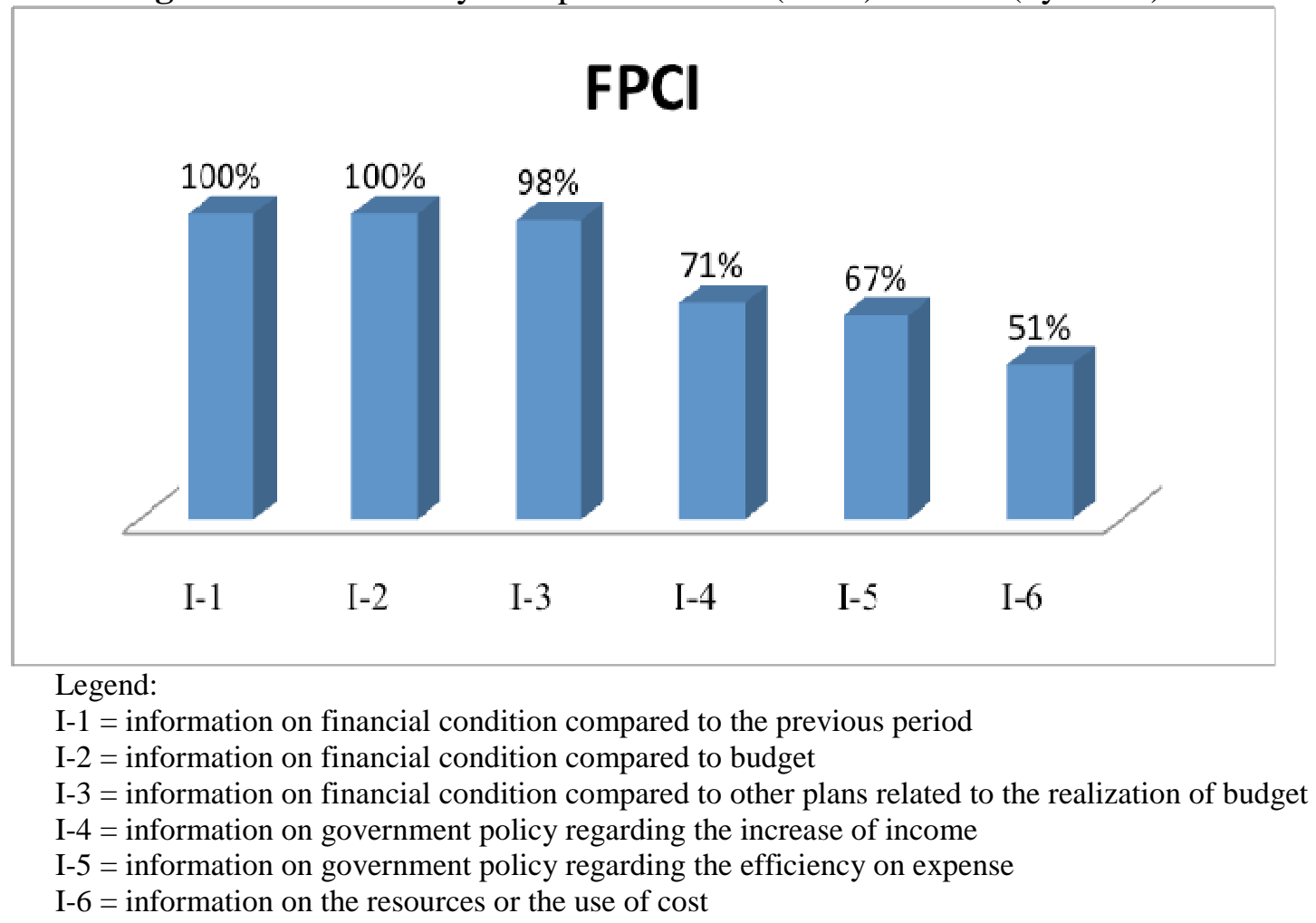

Key factors highlighted from Figure 1 are:

- The average overall information on fiscal policy (FPCI) score during 2009 shows a high level of communication $(81.2 \%)$. This indicates that Indonesian local governments are very concerned about fiscal policy information which occurs in their area such as changes in financial position, revenue increases, expenditure efficiency, and the resources or the use of cost. Information on the position and financial condition is the highest communicated (100\%). Information on resources or the uses of cost are the lowest communicated (51\%).

- Two items in the FPCI, information on position and financial condition of the current period of fiscal compared to the previous one and position and financial condition of the current period of fiscal compared to a budget are communicated by all (100\%). This indicates that Indonesian local governments are very concerned about such information. The position of financial condition is compared with the previous year to determine changes, if there is a decline in quality between current and prior years, the improvement efforts can be made for further year. This is in accordance with one of the qualitative characteristics of financial statements in which the financial statements should be comparable (Schipper 2003).

- Information on government policies relating to increase of income is disclosed by $71 \%$ of the Indonesian local government entities. This indicates that not all local governments transparently disclose such information or may not yet know (or have acquired) the things that are needed to disclose relating to the policy.

- Information on government policies relating to the efficiency on expensed is communicated $67 \%$. This indicates that not all local governments in Indonesia disclose their efficiency on expense in their financial statements. One possible reason is that some local governments still use the traditional budget system that tends to spend their budget rather than set aside the budget expenditure for future years. 
- Information concerning the resources or the use of funds is only communicated by $51 \%$ of the entities. This indicates that numerous local governments are still not transparently providing information about revenue sources and its use in detail in their financial statements.

\section{Independent and Control Variables}

Size of local government can be measured by a variety of techniques. Size of council is measured by the number of local members in the parliament (e.g. Hix, 2004). This measurement is supported by the statement "the greater number of local parliament members reflects the greater pressure on the local government executive" (Sotiropoulos 2008, 29).

The location of entities whether they are located in Java or Non-Java is used as a proxy of the jurisdiction variable. It is measured by a dichotomous coding of Java (coded as 1) and Non-Java (coded as 0). The amenities and qualities of human resources in local governments located in Java are better than non-Java. Therefore, local governments which are located in Java potentially have better fiscal policy disclosure practices than Non-Java.

In Indonesia, the chairman of a local government may be from a political party or a coalition of political parties. Independence of local parliament is measured by the proportion of local parliament members who are independent of the executive (chairman of local government). Sloan (2011) argues that the greater proportion of the party that is independent to the executive will potentially raise the level of disclosure in financial statements.

The level of Human Development Index (HDI) is used as control variable. HDI is a comparative measure of life expectancy, average education level and standards of living for countries worldwide. A score is separately obtained for each jurisdiction in Indonesia. Local governments that have high HDI are expected to have better disclosure in their financial statements. This is because they receive greater pressure from the public (Nurhayati, Brown and Tower 2006).

Type of local government is measured by a dichotomous coding of municipality (coded as 1) and district (coded as 0). According to UU No.22 of 1999, Indonesian local government structure is divided into municipality (urban area) and district (rural area). Usman (2001) states that the type of local government usually reflects the economic development level and infrastructure. This focuses on how the municipality interacts with the community. Hence, municipality governments may be motivated to be more transparent in preparing their financial statements.

Age of an entity may affect the quality of its financial statements. The older the local government entity the likelihood of better quality because there has been a longer learning process (Lev and Schwartz 1971). The original number of local government entities in Indonesia before 1999 was 292, more recently because of new local government autonomy acts, that number has substantially grown to 496. Age of entity is measured by the number of years from inception of the local government.

The number of audit finding concerns is derived from the findings based on five classifications, including; state losses, lack of acceptance, administration, inefficiency, and ineffectiveness (BPKRI, 2009). The total number of documented concerns is used to measure the audit findings variable. This measurement is previously used in Martani and Lestiani (2010).

Surplus and deficit of a local government is measured using a dichotomous scale. If government revenue is greater than expenditure (surplus) then a score of 0 (zero) is given, whereas a score of 1 (one) is given if government revenue is less than expenditure (deficit). This coding is previously used in Stalebrink (2007) when examining the extent of disclosures in the financial statements of cities.

Finally, financial independence is measured by ratio of Local Government Financial Independence (RLGFI). According to Alicias et al. (2007) the local financial formula is calculated as the local government revenue divided local government revenue plus revenue from state and province. 
Table 2: Measurement Technique of the Independent and Control Variables

\begin{tabular}{|c|c|c|c|c|}
\hline & $\begin{array}{c}\text { Independent } \\
\text { Variables }\end{array}$ & $\begin{array}{l}\text { Control } \\
\text { Variables }\end{array}$ & Measurement & $\begin{array}{l}\text { Type of } \\
\text { Data }\end{array}$ \\
\hline $\begin{array}{l}\text { Coercive isomor- } \\
\text { phism }\end{array}$ & $\begin{array}{l}\text { Size of local } \\
\text { g® ernment }\end{array}$ & & $\begin{array}{l}\text { Total number of local government parliamen- } \\
\text { tarians }\end{array}$ & Continuous \\
\hline $\begin{array}{l}\text { Mimetic isomor- } \\
\text { phism }\end{array}$ & Jurisdiction & & $\begin{array}{l}\text { It is measured by dichotomous coding: } \\
1=\text { if local government entity is located in } \\
\text { Java } \\
0=\text { if local government entity is not located in } \\
\text { Java }\end{array}$ & Categorical \\
\hline \multirow[t]{8}{*}{$\begin{array}{l}\text { Normative isomo } \\
\text { phism }\end{array}$} & $\begin{array}{l}\text { Political Influ- } \\
\text { ence }\end{array}$ & & $\begin{array}{l}\text { Proportion of non controlling parties in the } \\
\text { local parliament }\end{array}$ & Continuous \\
\hline & & HDI & Level of Human Developing Index (HDI) & Continuous \\
\hline & & $\begin{array}{l}\text { Type of local } \\
\text { government }\end{array}$ & $\begin{array}{l}1=\text { Municipality } \\
0=\text { District }\end{array}$ & Categorical \\
\hline & & Age of entity & Number of years from inception & Continuous \\
\hline & & Audit Finding & Number of audit finding recommendations & Continuous \\
\hline & & $\begin{array}{l}\text { Surplus/deficit } \\
\text { of Local } \\
\text { Government }\end{array}$ & $\begin{array}{l}1=\text { if deficit }(\text { revenue }<\text { expenditure }) \\
0=\text { if surplus }(\text { revenue }>\text { expenditure) }\end{array}$ & Categorical \\
\hline & & & Local government revenue & \\
\hline & & $\begin{array}{l}\text { Financial inde- } \\
\text { pendence }\end{array}$ & $\begin{array}{l}\text { Local government revenue }+ \text { Revenue } \\
\text { from state/province }\end{array}$ & Continuous \\
\hline
\end{tabular}

\section{RESULTS AND DISCUSSION Descriptive Results and FPCI Analysis}

Table 3: Descriptive Statistics of the Dependent, Independent and Control Variables

\begin{tabular}{lcccccc}
\hline \multicolumn{1}{c}{ Variable } & $\mathrm{n}$ & $\begin{array}{c}\text { Min } \\
(\%)\end{array}$ & $\begin{array}{c}\text { Max } \\
(\%)\end{array}$ & $\begin{array}{c}\text { Mean } \\
(\%)\end{array}$ & $\begin{array}{c}\text { Median } \\
(\%)\end{array}$ & $\begin{array}{c}\text { Std Dev } \\
(\%)\end{array}$ \\
\hline Fiscal Policy Compliance Index (FPCI) & 80 & 51 & 100 & 81.2 & 84.5 & 21.01 \\
Number of Parliamentarians & 80 & 20 & 50 & 39 & 42 & 9.50 \\
Human Development Index (HDI) & 80 & 61.27 & 81.94 & 72 & 72.20 & 3.60 \\
Non Supporting Parties & 80 & 28.60 & 96 & 67 & 66.70 & 13.80 \\
Age of Local Government & 80 & 3 & 1328 & 278 & 158 & 333 \\
Audit Finding & 80 & 8 & 47 & 23 & 22.51 & 7.60 \\
Financial Independence & 80 & 1 & 30 & 9.60 & 8 & 5.90 \\
\hline
\end{tabular}

Legend: Table 3 shows the descriptive statistics of dependent variable (FPCI) and continuous predictor variables Whereas the composition of categorical variables consist of $17.5 \%$ (deficit entities) and $82.5 \%$ (surplus entities), $50 \%$ (Java) and 50\% (Non-Java), 50\% (district) and 50\% (municipality).

Table 3 shows that the average of Fiscal Policy Compliance Index (FPCI) level for the 80 Indonesian local governments is $81.2 \%$. This finding suggests that overall fiscal policy disclosure practices of Indonesian local governments are high. The number of local parliament members in the 80 local governments range from 20 to 50 persons with the mean of 39 persons. This is in accordance with the regulation of Indonesian electoral commission No. 17 of 2008 that the number of local parliament members shall be at least 20 seats and at most 50 seats. The Human Development 
Index (HDI) scores for Indonesian local governments are quite varied.

The minimum score of the HDI for the 80 local governments is $61.27 \%$ (West Lombok, Java non-district) and the maximum score is $81.94 \%$ (Tasikmalaya, Java-district) with the average value of all local governments being $72 \%$. The proportion of minority parties in each local parliament also has a wide range whith the lowest proportion being Cilegon (Java-municipality) with $28 \%$, while the highest is Cimahi (Java-municipality) with $96 \%$. Interestingly, local governments in Indonesia have greatly varying ages. The newest local government is the 3 years old Bengkulu Tengah (Non Java-district), while Palembang (Non Java-municipalty) is the oldest that has been in existence for over a millennium being 1327 years. The local government having the lowest number of audit finding is Sleman (Java-district) with 8 findings, whereas the largest number of audit finding is Cianjur (Java-district) with 47 findings. Finally, the minimum value of financial independence variable is 1 (Bengkulu Tengah, Non Javadistrict), and the highest is 30 , the average value is 9.60 (Surabaya, Java-municipality).

Table 4 shows significant statistical differences for several predictor variables include Number of Parliamentarians, Human Development Index, Non-Supporting Parties, Age of Local Government, Audit Finding, and Financial Independence between Java and Non Java local governments, districtmunicipality, and surplus-deficit local governments. There are three variables that are high statistically significantly different between Java and Non-Java local governments such as Number of Parliamentarians (pvalue $=0.001)$, Financial Independence (pvalue $=0.001)$ and Audit Finding (pvalue $=0.003$ ). In addition, two other variables are statistically significantly different, these are the Human Development Index (pvalue $=0.017)$ and Audit Finding (pvalue $=0.021)$. There is one variable that is not significantly different between Java and Non Java local governments, that variable is Non Supporting Parties. This finding notes no difference between minority parties in Java and Non Java.

Furthermore, variables of Human Development Index and Financial Independence between Indonesian municipalities and districts are high statistically significantly different (pvalue $=0.000$ ). These results indicate that both variables are likely strongly influenced by geographic position of local governments, which are located in municipalities or districts. There are no significantly different findings for other variables.

Table 4 also generates the results of univariate tests associated with all predictor variables categorized based on local government budget surpluses and deficits. The statistical analysis shows that audit finding and financial independence between budget surplus and deficit local governments have statistically significant differences ( $p$-value $=0.012$ and 0.023 ). Both variables are influenced by the condition of local government budget.

Table 4: Univariate Analysis Results: Anova and T-Test

\begin{tabular}{llll}
\hline \multicolumn{1}{c}{ Variable } & Java-Non Java & $\begin{array}{c}\text { District- } \\
\text { Municipality }\end{array}$ & Surplus-Deficit \\
\hline Number of Parliamentarians & $.001 * * *$ & .428 & .579 \\
Human Development Index (HDI) & $.017^{* *}$ & $.000^{* * *}$ & .352 \\
Non Supporting Parties & .585 & .794 & .988 \\
Age of Local Government & $.021^{* *}$ & .288 & .524 \\
Audit Finding & $.003^{* * *}$ & .377 & $.012 * *$ \\
Financial Independence (a) & $.001 * * *$ & $.000^{* * *}$ & $.023^{* *}$ \\
\hline
\end{tabular}

**kighly significant at $1 \%$ level, **significant at 5\% level, *moderately significant at $10 \%$ level.

Legend: (a) financial independence variable consist of 66 deficit entities +14 surplus entities 
Table 5: ANOVA Analysis by Category Jurisdictions in Indonesia

\begin{tabular}{lrrrrrrr}
\hline \multicolumn{1}{c}{ Variable } & \multicolumn{1}{c}{$\begin{array}{c}\text { HDI } \\
(\boldsymbol{\%})\end{array}$} & \multicolumn{1}{c}{$\begin{array}{c}\text { Age } \\
(\mathbf{y e a r s})\end{array}$} & \multicolumn{1}{c}{$\begin{array}{c}\text { NumPar } \\
(\#)\end{array}$} & $\begin{array}{c}\text { Audfind } \\
(\#)\end{array}$ & $\begin{array}{c}\text { Indepcy } \\
(\#)\end{array}$ & \multicolumn{1}{c}{$\begin{array}{c}\text { Nonsup } \\
(\boldsymbol{\%})\end{array}$} \\
\hline Java Districts & 72.2 & 368 & 46 & 20 & 8.9 & 67.5 \\
Non Java Districts & 69.3 & 109 & 33 & 23 & 4.0 & 67.9 \\
Java Municipality & 75.1 & 359 & 36 & 20 & 14.8 & 68.8 \\
Non Java Municipality & 74.1 & 277 & 38 & 27 & 10.8 & 65.0 \\
Average & 72.7 & 278 & 38 & 22 & 9.6 & 67.3 \\
Min & 61.2 & 3.0 & 20 & 8 & 1.0 & 28.6 \\
Max & 81.9 & 1327 & 50 & 47 & 30.0 & 96.0 \\
Sig (p-values) & $\mathbf{0 . 0 0 0 * * *}$ & $\mathbf{. 0 4 7 *}$ & $\mathbf{0 . 0 0 0 * * *}$ & $\mathbf{0 . 0 1 0} * *$ & $\mathbf{0 . 0 0 0}$ & $\mathbf{0 . 8 5 0}$ \\
F & 14.873 & 2.777 & 9.015 & 4.012 & 19.926 & 0.265 \\
\hline
\end{tabular}

**kighly significant at $1 \%$ level, $* *$ significant at $5 \%$ level, *moderately significant at $10 \%$ level.

Legend: HDI=Human Development Index; Age=Age of local government; Numpar=Number of parliamentarians;

Audfind=Audit finding; Indepcy=Financial Independence; Nonsup=Non supporting parties

Table 5 shows quite interesting information regarding the predictor variables associated with the condition of the four local government jurisdictions in Indonesia (1) Java District, (2) Non Java District, (3) Java Municipality, (4) Non Java Municipality. The table highlights highly significant differences by the types of their jurisdiction, namely Java district, Non-Java district, Java municipality, and Non-Java municipality. The statistical differences include the HDI quality of life measure ( $p$-value $=0.000$ ), number of elected official in the local area $(p-v a l u e=0.000)$, financial independence of the local government (pvalue $=0.000)$ and number of critical audit findings ( $p$-value $\theta .010$ ). Moreover, it can be seen that age of local government is also significantly different ( $\mathrm{p}$-value $\theta .047$ ). Only the non-supporting parties variable is not significantly different ( $\mathrm{p}$-value $=0.850$ ).

\section{Regression Analysis}

To test the three hypotheses, a series of backward regression are performed ${ }^{4}$. In such a regression, all predictor variables are entered into a model and sequentially removed until only significant variables remain with the

\footnotetext{
Classical assumptions of multiple regression (multicollinearity, normality, linearity, outliers, and homoscedasticity) have been checked with the conclusion that all of the assumptions were met (see Hair, Anderson, Tatham \& Black 1988).
}

maximum explanatory power (Cooper and Schindler 2006).

Table 6 multiple regression results shows that number of parliamentarians (coercive variable) influences the Indonesia Fiscal Policy Compliance Index (FPCI). This variable is statistically significant (p-value 0.018). Furthermore, the value of adjusted R-square is $24.9 \%$. There are two control variables which are statistically significant, they are age of local government $(p$-value $=0.025)$ and financial independence ( $\mathrm{p}$-value $=0.022)$. The coefficient of the three variables are positive, supporting the argument presented in prior section which posits that there are positive associations between fiscal policy mandatory disclosure practices and the size of local government as represented by the number of parliamentarians (Hypothesis 1), age of local government (control variable) and financial independence (control variable). However, the other hypotheses variables such as Java and Non Java (Hypothesis 2), non-supporting parties (Hypothesis 3) and control variables (HDI, audit finding, municipality-district, and surplus-deficit) are not statistically significant and therefore they are considered unable to explain the variation of fiscal policy disclosure practices in Indonesian local governments. 
Table 6: Result of Backward Regression

\begin{tabular}{lcccc}
\hline \multicolumn{1}{c}{ Variables } & $\begin{array}{c}\text { Variable } \\
\text { Types }\end{array}$ & Predicted Sign & Coefficient & P-Value \\
\hline (Constant) & & & .462 & .000 \\
Number of Parliamentarians & IV & + & .002 & $.018^{* *}$ \\
Age of local government & CV & + & .000 & $.025^{* *}$ \\
Financial independence & CV & + & .004 & $.022^{* *}$ \\
Adjusted $\mathrm{R}^{2}: .249$ & & & & \\
F-Stat $: 9.740$ & & & & \\
Sig. : .000 & & & & \\
\hline
\end{tabular}

Legend: IV=Independent Variable; $\mathrm{CV}=$ Control Variable

**highly significant at $1 \%$ level, **significant at $5 \%$ level, *moderately significant at $10 \%$ level.

\section{CONCLUSION}

The research presented in this paper focuses on an empirical analysis of the veracity of isomorphic institutional theory to predict the level of fiscal policy mandatory disclosure practices in Indonesia local governments. An Indonesian Fiscal Policy Compliance Index (FPCI) checklist is created with key predictor variables (size of local parliament, Java-Non Java, and non supporting parties) tested to explain the extent of such communication in 2009.

In summary, from the three isomorphic components including coercive, mimetic, and normative, only the coercive component has a significant effect on the extent of fiscal policy disclosure (number of parliamentarians). This generates evidence that in Indonesia, coercive pressure is still needed to improve transparency. This is consistent with Graham and Woods (2006) argument that coercive pressure is effective in developing countries.

Local parliament is often very concerned about fiscal policy of local governments. Dillon (2002) states that Local parliament has a strategic role in alleviation program of Indonesia's poverty through establishment of regional regulation relating to fiscal policy. In Indonesia, poverty reduction arguably has sufficient funds from their local budgets because it is fully supported by the local parliament. Therefore, the local parliament is very concerned about information of fiscal policy in the financial statements of local governments. Furthermore, Kartiwa (2009) states that one of local parliament functions is to formulate development policies and to plan development programs in the region including fiscal policy. The findings in this study reveal that the local parliament generates pressure (coercive pressure) on the local government to disclose fiscal policy information in its financial statement.

In addition, age of local government affects the extent of fiscal policy disclosure in Indonesian local governments. This finding supports Lev and Schwartz (1971) statement that the older the age of the entity leads to the likelihood of better quality because there has already been a long learning process. Finally, financial independence also influences the extent of fiscal policy disclosure. The higher the level of financial dependence, the more extensive disclosure of fiscal policies of local government financial reports. This is probably because the central government as the supporter of funds will ask for more detailed explanations from local governments which have higher levels of financial dependence as an evaluation tool in the following years. Thus, the local governments with higher financial dependence tend to be more expansive in disclosing fiscal policy information in their financial statements. This finding in line with Rajan and Zingales (1996) statement that organizations with high financial dependence tend to be more open in their financial accountability.

Furthermore, a key finding in this research is that the Indonesian overall level of communication as measured by the FPCI score is $81.2 \%$. Arguably, this is a good level of transparency. Several items are communi- 
cated very well by Indonesian local governments (above $90 \%$ even up to $100 \%$ ). Nevertheless the government should try to enhance the level of fiscal policy disclosure, particularly information relating to their resources and costs $(51 \%)$, information on government policy regarding the efficiency on expenses (67\%), and information on government policy regarding increases in income $(71 \%)$.

Transparency can be improved when there are clarity of tasks and authority, availability of information to public, open budgeting process, and guarantees of integrity regarding fiscal forecasts, information, and sufficient detail (Campo and Tomasi 1999). Therefore, the government should continue their efforts to improve transparency in local government as one important aspect of public governance in Indonesia.

\section{REFERENCES}

Alicias, D., M. Djadijono, and T. A. Legowo. 2007. Decentralization interrupted: studies from Cambodia, Indonesia, Philippines and Thailand. Quezon City: Institute for Popular Democracy for Learning Initiative on Citizen Participation and Local Governance.

Ashworth, R., G. Boyne, and R. Delbridge. 2007. Escape from the iron cage? organizational change and isomorphic pressures in the public sector. Journal of Public Administration Research and Theory 19 (1): 165-187.

Baker, R., and M. Rennie. 2006. Forces leading to the adoption of accrual accounting by the Canadian Federal Government: an institutional perspective. $\mathrm{Ca}$ nadian Accounting Perspectives 5 (1): 83-112.

Ball, R. 2001. Infrastructure requirements for an economically efficient system of public financial reporting and disclosure. Brookings-Wharton Papers on Financial Services, p. 127-169.
Biro Pusat Statistik (BPS). 2010, 29 April. Kompas, p. 3.

Buhr, N., and M. Freedman. 2001. Culture, institutional factors and differences in environmental disclosure between Canada and United States. Critical Perspectives on Accounting 12 (1): 293-322.

Campo, S., and D. Tomasi. 1999. Managing government expenditure. Manila: Asia Development Bank.

Carpenter L., and F. Ehsan. 2001. Institutional theory and accounting rule choice: an analysis of four US state government' decisions to adopt generally accepted accounting principles. Accounting Organizations and Society 26 (1): 565596.

Cheng, R. H. 1992. An empirical analysis of theories on factors influencing state government accounting disclosure. Journal of Accounting and Public Policy 11 (1): 1-42.

Cook, D., and D. M. Hawkins. 1990. Unmasking multivariate outliers and leverage points. Journal of the American Statistical Association 85 (411): 640-644.

Cooper, D. R., and P. S. Schindler. 2006. Business research methods (ninth edition). New York: McGraw-Hill.

Copley, P. A. 1991. The association between municipality disclosure practices and audit quality. Journal of Accounting and Public Policy 10 (4): 245-266.

Covaleski, M. A., and M. W. Dirmith. 1988 . An institutional perspective on the rise, social transformation, and fall of a university budget. Administrative Science Quarterly 33 (3): 562-587.

Coy, D., G. Tower, and K. Dixon. 1993. Quantifying the quality of tertiary education annual reports. Accounting Finance 33 (2): 121-129.

Craig, R., and J. Diga. 1998. Corporate accounting disclosure in ASEAN. Jour- 
nal of International Financial Management and Accounting 9 (3): 246274.

Dacin, M. T. 1977. Isomorphism in context: the power and prescription of institutional norms. Academy of Management Journal 40 (1): 46-81.

Deegan, C. 2006. Financial accounting theory (second edition). Sydney: McGrawHill.

Dillon, H. S. 2002. Kebijakan dan strategi penanggulangan kemiskinan di Indonesia. Dinamika Pedesaan dan Kawasan 2 (2): 41-52.

DiMaggio, P. J., and W. W. Powell. 1983. The iron cage revisited: institutional isomorphism and collective rationality in organizational fields. American Sociological 48 (2): 146-160.

Graham, D., and N. Woods. 2006. Making corporate self-regulation effective in developing countries. World Development 34 (5): 868-883.

Grigorescu, A. 2008. Horizontal accountability in intergovernmental organizations. Ethics in International Affairs 22 (3): 285-308.

Hair, J. F., R. E. Anderson, R. L. Tatham, and W. C. Black. 1998. Multivariate data analysis (fifth edition). New Jersey: Prentice-Hall, Inc.

Herawaty, A., and Y. K. Susanto. 2008. Profesionalisme, pengetahuan akuntan publik dalam mendeteksi kekeliruan, etika profesi dan pertimbangan tingkat materialitas. The $2^{\text {nd }}$ National Conference $U K W M S$, Surabaya, Indonesia.

Hix, S. 2004. Electoral institutions and legislative behavior: explaining voting defection in the European parliament world politics. World Politics 56 (2): 194223.

Ingram, R. W., and D. V. DeJong. 1987. The effect of regulation on local government disclosure practices. Journal of
Accounting and Public Policy 6 (4): 245-270.

Joseph, C. 2010. Sustainability reporting on Malaysian local authority websites, Unpublished Doctoral Thesis, Curtin University, Perth, Australia.

Kartiwa, H.A. 2009. Implementasi peran dan fungsi DPRD dalam rangka mewujudkan good governance. Repository Universitas Padjajaran, retrieved from http://repository.unpad.ac.id/handle/ 123456789/1819

Komite Standar Akuntansi Pemerintahan. 2005. Peraturan pemerintah nomor 24 tahun 2005 tentang standar akuntansi pemerintahan. Jakarta: Salemba Empat.

Kostova, T., and S. Zaheer. 1999. Organizational legitimacy under conditions of complexity: the case of multinational enterprise. The Academy of Management Journal 24 (1): 64-81.

Lev, B., and A. Schwartz. 1971. On the use of economic concept of human capital in financial statements. The Accounting Review 46 (1): 103-112.

Lyngstad, R. 2010. Reconsidering rationales for local self-government impacts of contemporary changes in local decision making. Journal of Local SelfGovernment 8 (1): 93-113.

Mahoney, J. T., and J. Kim. 2005. Property rights theory, transaction costs theory, and agency theory: an organizational economics approach to strategic management. Managerial and Decission Economics 26 (4): 223-242.

Mardiasmo. 2002. Elaborasi reformasi akuntansi sektor publik: telaah kritis terhadap upaya aktualisasi kebutuhan sistem akuntansi keuangan pemerintah daerah. Jurnal Akuntansi dan Auditing Indonesia 6 (1): 63-82.

Martani, D., and A. Lestiani. 2010. Local government financial statement disclosure 
in Indonesia. University of Indonesia. Annual Meeting and Conference Asian Academic Accounting Association (AAAA), Bangkok, Thailand.

Meek, G. K., C. B. Roberts, and S. C. Gray. 1995. Factors influencing voluntary annual report disclosures by US, UK and continental European multinational corporations. Journal of International Business Studies 26 (3): 555572.

Meyer, J. W., and B. Rowan. 1977. Institutionalized organizations: formal structures as myth and ceremony. American Journal of Sociology 83 (2): 310-363.

Mobus, J. L. 2005. Mandatory environmental disclosures in a legitimacy theory context. Accounting, Auditing \& Accountability Journal 18 (4): 492-517.

Mucciarone, M. A. 2008. Accountability and performance measurement in Australian and Malaysian government department. Unpublished Doctoral Thesis, Curtin University, Perth, Australia.

Nurhayati, R., A. M. Brown, and G. Tower 2006. Understanding the level of natural environmental disclosures by Indonesian listed companies. Journal of the Asia Pacific Centre for Environmental Accountability 12 (3): 4-11.

Palmer, I., and R. Dunford. 1993. Conflicting uses of metaphor: reconceptualizing their uses in the field of organizational change. Academy of Management Review 21 (3): 691-712.

Peraturan Menteri Dalam Negeri No. 13 tahun 2006, Pedoman Pengelolaan Keuangan Daerah, Retrieved 1 Juni 2011, from

http://hukum.unsrat.ac.id/men/permen dagri_13_2006.pdf

Perera, H. 2007. The international and cultural aspects of social accounting. In R. Gray \& J. Guthrie (Editors), social accounting, mega accounting, and beyond: A festschrift in honor of M.R.
Mathews (p. 91-99). St. Andrews: CSEAR Publishing.

Rahaman, A., Shiraz, S. Lawrence, and J. Roper. 2004. Social and environmental reporting at the VRA: institutionalised or legitimation crisis? Critical Perspectives on Accounting 15 (1): 35-56.

Rajan, R. G., and L. Zingales. 1996. Financial dependence and growth. American Economic Review 88 (3): 559-586.

Republik Indonesia. 2003. The Act. No 17, 2003. Retrieved from http://www.dmo.or.id./dmodata /4Peraturan_dan_Ketentuan/1Undang_ undang/UU_17_2003_ Keuangan Negara.pdf.

Reynolds, N. L, A. C. Simintiras, and A. Dímantopoulos. 2003. Theoritical justification of sampling choices in international marketing research: Key issues and guidelines for researches. Journal of International Business Studies 34 (1): 80-89.

Robbins, W. A., and K. R. Austin. 1986. Disclosure quality in governmental financial reports: an assessment of the appropriateness of a compound measure. Journal of Accounting Research 24 (2): 412-421.

Ryan, C., and B. Purcell. 2004. Corporate governance disclosures by local government authorities. Working Paper. Queensland University of Technology, Brisbane, Australia.

Schipper. 2003. Principles-Based Accounting Standards. Accounting Horizons 17 (2): 212-229

Schon, W. 2006. Corporate disclosure in a competitive environment-the quest for a European framework on mandatory disclosure. Journal of Corporate Law Studies 6 (2): 259-298.

Scott, W. R. 1987. The adolescence of institutional theory. Administrative Science Quarterly 32 (4): 493-511. 
Sejjaaka, S. 2004. A process based model for corporate mandatory disclosure. Retrieved from http://cpa.ug/A\%20Process\%20Based $\% 20$ Model $\% 20$ of $\% 20$ Corporate $\% 20$ Mandatory\%20Disclosure.pdf.

Silva, C. N. 2009. Local political leadership in Portugal: exceptionalism or convergence towards a 'mayoral model'? Journal of Local Self-Government 7 (3): 243-256.

Sloan, L. 2011. Measuring minor parties in English local government: presence vs. vote share. Local Politics Specialist Group. Retrieved from http://www.psa.ac.uk/2011/ UploadedPaperPDFs /719_270.pdf.

Sopanah., and I. Wahyudi. 2010. The effect of public accountability, transparency of public policy, and public participation on relations between the knowledge of the budget by regional financial supervision. E-journal. Retrieved from UMM.ejournal.umm.ac.id/index.php/.. / 321_umm_scientific_journal.doc

Sotiropoulos, E. 2008. A reformed Senate as a check on prime ministerial power. $\mathrm{Ca}$ nadian Parliamentary Review 31 (1): 28-33.

Stalebrink, O. J. 2007. An investigation of discretionary accruals and surplusdeficit management: evidence from Swedish municipalities. Financial Accountability and Management 23 (4): 441-458.

Suliswanto, M. S. W., and D. Kaluge. 2010. Globalization and gross domestic product construction in Asean. Economic Journal of Emerging Markets 2 (2): 155-167.

Tagesson, T., and Falkman. 2008. Accrual accounting does not necessarily mean accrual accounting: factors that counteract compliance with accounting standards in Swedish municipality ac- counting. Scandinavian Journal of Management 24 (3): 271-283.

Talvi, E., and C. A. Vegh. 2005. Tax base variability and procyclical fiscal policy in developing countries. Journal of Development Economics 78 (1): 156190.

Taylor, J. B. 2000. Reassessing discretionary fiscal policy. Journal of Economic Perspectives 14 (3): 21-36.

Taylor, D. W, and M. Rosair. 2000. The effect of participating parties, the public and size on government departments' accountability disclosures in annual reports. Accounting, Accountability and Performance 6 (2): 77-98.

Tolbert, P. S., and L. G. Zucker. 1983. Institutional sources of change in the formal structure of organizations: the diffusion of civil service reform 1880-1935. Administrative Science Quarterly 28 (1): 22-39.

Undang-undangRepublik Indonesia No. 22 tahun 1999, Pemerintah Daerah, Retrieved 3 May 2011, from http://www.esdm.go.id/.../uu/.../270undang-undang-no22-tahun-1999.html.

Undang-undang Republik Indonesia No. 27 tahun 2009, Majelis Permusyawaratan Rakyat, Dewan Perwakilan Rakyat, Dewan Perwakilan Daerah, dan Dewan Perwakilan Rakyat Daerah, Retrieved 3 May 2011, from http://www.id.wikisource.org/ wiki/UndangUndang_Republik Indonesia_Nomor_27_Tahun_2009.

Usman S. 2001. Indonesia's decentralization policy, initial experiences and emerging problems. The Third EUROSEAS Conference Panel on Decentralization and Democratization in Southeast Asia. London, England.

Ying, Z., and L. Zhengfei. 2006. The Relationship between disclosure quality and cost of equity capital of listed 
companies in China. Economic Research Journal 2 (7): 275-297.

Yoshikawa, T., L. S. Tsui, and J. McGuire. 2007. Corporate governance reform as institutional innovation: the case of Ja- pan. Organization Science 18 (6): 973988.

Zucker, L. G. 1987. Institutional theories of organization. Annual Review of Sociology 13 (3): 443-464. 